\title{
Critically Analyse the Contribution Made by Qualitative Research to ELT (English Language Teaching) in China
}

\author{
Chanjuan Liu' ${ }^{1} \&$ Xindai Zhang ${ }^{2}$ \\ ${ }^{1}$ Queen's University Belfast, UK \\ ${ }^{2}$ Shandong University of Science and Technology, Tai'an, Shandong Province, China \\ Correspondence: ChanJuan Liu, School of Education, Queen’s University Belfast, UK. E-mail: cliu10@qub.ac.uk
}

Received: June 5, 2015 Accepted: June 22, 2015 Online Published: July 2, 2015

doi:10.5430/ijelt.v2n2p45 URL: http://dx.doi.org/10.5430/ijelt.v2n2p45

\begin{abstract}
The importance of research methodologies has been put into agenda over the last few decades in various disciplines - such as sociology, psychology, health care, nursing, education, arts and humanities, and so on .Application of qualitative approach as the practical research methodology in language education has shown an increasing rate. To achieve this aim ,the study first evidence a general overview from literature studies of the term, explore the definition, key characteristics of qualitative research.The second part investigated and analysed the underpinning theories and identify the strengths and weaknesses in a brief comparison with quantitative research. The third part analysed three published journal papers and argued research in the field of ELT and where its adoption in the future could be used.
\end{abstract}

Keywords: Qualitative research, Interpretivism, ELT, Contribution, published journal papers

\section{Introduction}

\subsection{Context of the Study}

The current situation of education research today strongly suggests that its validity as a field is being questioned and there is trust crisis of epistemology (Furlong, 1996). As noted by Woodhead (1998), "there is too much to do in the real world with real teachers in real schools to worry about methodological quarrels or to waste time decoding something pointless." Hence, as a contributing factor to educational improvement, the significance of research methodologies have been more and more going deep into acting over the last few decades (Hargreaves, 1997; Hillage et al., 1998; Tolley and Darby, 1998).

As one of the two main research strategies, qualitative research has been adopted in various disciplines such as social psychology, nursing, education, applied linguistics, language teaching and learning. According to Adamson (2004), "English has been taught in China for over 500 years." For the last two decades, English language education has been a paramount field of value and effectiveness, and English proficiency has been viewed as an asset which is both national and personal (Cortazzi \& Jin, 1996; Adamson, 2001; Hu, 2002a; Jin \& Cortazzi, 2003). However, there is a view that ELT as a grand occupation in the reform and renovation, fails to meet the requirements of the rapid development of society with growing contact with the external world (Qin, 1999). For one thing, empiricism without scientific research paradigms as guidance prevails at such a high level of abstraction; for the other, simple accumulation with no strict methodology for assessment and analysis has been raised as a question (Shu and Hua, 2009). Hence the important research methods in language education can never be overemphasised. In this setting, many foreign and local teachers are negotiating traditional and dominant discourses and practices about the English language and English Language Teaching (ELT) methods (McPherron, 2008).

In recent years, research designs from qualitative approaches as the practical methodology in different fields of study such as the social sciences has shown an increasing rate (Tavallaei and Talib, 2010a). Richard (2009) analysed papers published in 15 journals relevant to the field of language teaching, and discussed current trends and debates in the general area of qualitative research since the year 2000. He has highlighted praiseworthy contributions to the field and identified issues that have emerged in the new century. He claimed that qualitative research over the years has established a grand methodological ancestry with many valuable contributions to language teaching and learning. Likewise, Merriam (2014) stated that, the evolution of qualitative research as a sophisticated area of study has taken 
place and this is evident in the literatures, special interests, research journals and scheduled conferences. For instance, researchers have continued to have its important contribution based on our knowledge of language classrooms activities, and studies of teachers' concepts of communicative language teaching and their approaches to it are growing rapidly (Miller \& Aldred 2000; Mangubhai et al. 2004, 2005; Nazari 2007).Nevertheless, even though virtue of qualitative research is seldom doubted, its practice is sometimes criticised as being non-scientific and invalid (Berg, 2004). To illustrate this point further, Bryman and Burgess (1999) asserted that although there have been prolific writings on qualitative research since the 1970s, it is by no means a distinct research method. Ryman (2012) has argued as a research strategy that usually employs words instead of collecting and analysing data, qualitative research and analytic strategies are neither associated with high-tech society nor dominate the social sciences like quantitative research does. However, despite these drawbacks and controversies, it is important to recognise that still -existing prejudice and it is necessary to set forth a defence for it.

\subsection{The Purpose of Study}

Qualitative research has become an increasingly important aspect in the sociology and anthropology of education (Rahman, 2014). In the field of education studies, ELT researchers increasingly use qualitative inquiry (Richards, 2009). The core of this study is to identify those areas in language teaching where qualitative research as one of the two main research methodologies has the greatest quality of contribution, and indicate what needs to be done to further draw out of its potential. The study will be divided into three parts. The first part will briefly evidence a general overview from literature studies of the term, explore the definition, key characteristics and review key publications on qualitative research practice. The second part will investigate and analyse the theories underpinning qualitative research and identify the strengths and weaknesses in a brief comparison with quantitative research. The third part will illustrate by cases of published research, that is: analyse three published journal papers and argue that the qualitative paradigm is more contributive than any other research paradigms to ELT. Conclusions will then be drawn about the suitability of qualitative research in the field of ELT and where its adoption in the future could be used.

\section{Literature Review}

\subsection{Definition}

Qualitative research is part of a complicated historical field and means different things at different moments. Different writers define it distinctively. Nonetheless, an initial genetic definition can be offered. Tavallaei \& Talib (2010b) proposed that an adequate definition of qualitative research must be able to grab the essential characteristics of a broad and disputed field. The definition closest to achieving this is provided by Denzin \& Lincoln (2000), who suggest that qualitative is a multimethod clearly involving an interpretive approach to the subjects with naturalistic features. This definition focuses on methods. Also, they regard "qualitative approaches to educational research "comprise a range of interpretive, material practices that transform the world into sets of presentations including field notes, interviews, conversations, photographs, recordings, and memos to the self". This means that qualitative researchers study things in their natural settings, but attempt to make sense of phenomena in terms of their meanings. Furthermore, some writers define qualitative research in terms of what it is not. For example, as Strauss and Corbin (1998, p.17) claimed "It is any kind of research that produces findings not arrived by means of statistic procedures or other means of quantification." They described qualitative research as any research not primarily based on counting or quantifying empirical materials. To conclude, the overall discussion so far states that qualitative research is neither statistical nor quantifiable, and it refers to the way people interpret the world and the experiences they have in the society (Holloway and Wheeler, 2013).

\subsection{Characteristics}

Given the definitions so far, a clarification and delineation of characteristics of qualitative as opposed to quantitative research will be demonstrated next. At the outset, for one thing, quantitative research is to analyse digital numbers, describe results, explain phenomena or complex educational issues by accurate means, and interpret complicated educational problems using mathematically based methods (Aliaga \& Gunderson, 2000). For the other, Denzin and Lincon (1994, p. 2) stated that "qualitative research is a multi-method in focus, involving an interpretive, naturalistic approach to its subject matter." What should be noted here is that the more significant role of the umbrella term qualitative research comprises a number of disciplines, primarily anthropology, sociology and philosophy, and it is used in almost all social fields' inquiry (Heigham and Croker, 2009).

Then, despite the diversity and the sometimes conflicting nature of inherent claims about its qualities, a number of 
writers have endeavoured to grasp the essence focused on key aspects of methodology of qualitative research (Bryman, 1988; Denzin and Lincoln, 2000; Hammersley and Atkinson, 1995; Holloway and Wheeler, 1996; Mason, 2002; Miles and Huberman, 1994; Patton, 2002)." These key aspects are defining characteristics of qualitative research and the way it differs from quantitative research can be summarized as follows: "holistic research approaches, important reference frameworks of participants, flexible research design; rich qualitative data; various ways of analysis and interpretation; and the derived outputs (Ritchie et al., 2013)." Whilst some others summed up the characteristics into: "(1) the detailed observation which involves researchers in the natural setting where the study occurs, (2) the effort to stay away from the philosophies or hypotheses constructed before collecting any data (Yin, 1984)."

Furthermore, in metaphorical terms, quantitative is hard while the qualitative is soft (Nunan, 1992).From the traditional view, quantitative is considered obstructive and objective, outcome -oriented and results external to or independent from the observers and researchers. But qualitative method, on the other hand, assumes all knowledge subjective; capable of being justified, not just studies the specific cases, but more general conclusions or agreements that can pragmatically support research proposals. According to Gall et al (1998): "it answers not only questions of how much, but other issues like what, why and how in nature." As stated by Denzin and Lincoln (1994, p. 2): "qualitative research involves the studied use and collection of a variety of empirical materials - case study, personal experience, introspective, life story, interview, ,observational, historical, interactional, visual texts that describe routine and problematic moments and affairs in individuals lives." Establishing an inductive reasoning, as well as thorough analysis is very common in qualitative research (Truk, Powell and Meyer, 1995). Ponterotto (2006) referred to it as a thick description where qualitative researchers both describe and interpret observed social action (or behaviour) within its particular context, instead of providing a thin description simply reporting acts and situations (Dezin, 1989).

Based on the comparison and contrast of qualitative and quantitative research paradigms, the next section aims to present and appraise the interpretivism research as the consolidate theory of qualitative research.

\subsection{Underpinning Theories of Qualitative Research}

\section{Interpretivism: origins, beliefs, and practices}

In the late twentieth century, there was a view that the subject matter or theme of social science (people and institutions) is quite distinct from that of the natural world. Accordingly, the subjective meaning of social action is required to be identified by the interpretive paradigm alternative to positivism (Bryman, 2012). Obviously, positivism and interpretivism do not exist independently of each other. In this section, the brief comparison of them should be appraised before given to anchor research.

The interpretivism differs from positivism in the following aspects: First, positivists are usually identified as naturalists with quantitative methods and present their perspective as only one logic of inference (Blalock 1982, 1989; Friedman 1953; Goldthorpe 2000; King, Keohane, Verba 1994; Lazarsfeld, Rosenberg 1955; Lieberson 1985; Wilson 1998). Oppositely, interpretivists suggest that there might be multiple logics at work in the social sciences instead of a unified one (Gerring and Thomas, 2011). Second, positivists make efforts to identify causes that influence outcomes (Creswell, 2009, p. 7). This is a nomothetic approach identified by Cohen et al. (2007) which discovers general laws. In contrast, interpretive methodology aims at understanding phenomenon from a persons' perspective and investigating interaction among people within the historical and cultural contexts they live in (Creswell, 2009). As Seymour and Davies (2002) have stated, the interpretivist paradigm is not only about people but also for them. Third, positivism is the valid knowledge to verify peoples' sense, experience, and precisely postulate scientific knowledge (Larrain and Ozanne, 1979). The positivist tends to be realistic and suppose that concrete objective reality exist in its own right of individuals' perception and the social world (Johnson, 1992). Conversely, the term interpretivism, as a social science epistemology, is an ideographic study of individual cases or events: "interpretive researchers assume that access to reality is only through social constructions such as language, consciousness, shared meanings, and instruments" (Myers, 2008, p.38).

To conclude, some scholars agreed that it is impossible to reconcile the great differences between these two paradigms (e.g. Orlikowski \&Baroudi, 1991; Walsham, 1993, 1995). The differences in the use and the conclusions of their work have led purists in both camps to assert that these two systems cannot be combined (Brooke, 2013).

Oppositely, some other scholars have made attempts to narrow down the differences and propose neutral views (Lee, 1991; Weber, 2004; Fitzgerald \& Howcroft 1998). Whist Kelin and Myers (cited in Kroze, 2012) tried to prove no distinction between them. Lin (1998) even argued absolute opinions for one or the other approach are wrong; the 
combination of both makes more sense. Howe (1992) made this argument by denying there is an "either-or" choice to be made. Rather, he claimed that both quantitative and qualitative researchers should accept positivism shaped by a certain degree of interpretivism, proposing an adjustment made by the critical social (or research) model which avoids the positivist-interpretivist split to achieve harmony.

However, it may be appropriate to subscribe to the ideas of Orlikowski \& Baroudi (1991) and Walsham, (1993, 1995). They addressed how the nature and purpose of interpretive research are different from positivist research. The debate about positivism versus interpretivism has been discussed like: "interpretivism developed as a response to the objectivism and excessive rationalization of the positivist approach (Willis, 2007)." Additionally, in the words of Geertz (1973), "positivists are more likely to use an approach that adopts the logic of statistical inference to qualitative work, while interpretivists employ "thick description" of the research site". All the above formulations indicate that interpretivism and positivism are paradigms distinct to each other. Positivism has been dominant in history, but in recent years, interpretivism has become more important as it grew in different disciplines such as phenomenology/sociology and anthropology (Brooke, 2013). In ELT practice, choosing the right criteria is necessary for the policymaking purpose and the necessity of identifying both is even more compelling. Therefore, it might be right to refute the neural claims.

\section{Interpretivism: Schools of thought}

There are several different schools of thought involved in interpretivism: Symbolic interactionism, phenomenology, ethnomethodology, ethnography, grounded theory and so on.

Some authors have confirmed that symbolic interactionism, and ethnomethodology are basically the same (e.g., Denzin, 1970; Rock, 1979; Petras andMeltzer), while others (Zimmerman and Wieder, 1970; Gilsinan, 1973; Perinbanayagam, 1974, 1975) have given a qualified "no". They are apparently similar in topic and approach and are radically different sociological perspectives (Denis, 2011). Initially, their similarities can be taken into account: Practitioners of both have doubts about earlier theories (Blumer 1969; Sharrock and Anderson, 1982) and suggest applying theoretical techniques to investigate the social world. Both favor undertaking such investigations with qualitative methods, particularly ethnographies (Becker and Geer, 1957; Garfinkel 2002, p.248). Finally, both reject to the idea that there can be an "objective" description of social interaction.

There are, however, significant differences between them. On the one hand, for symbolic interactionists, the sense of interaction depends entirely on actors' interpretations and understandings (Blumer1969, p.2), while for ethnomethodologists the meaning of any interactional "move" is automatically bound to its context(Garfinkel, 1967).On the other hand, symbolic interactionists have rightly argued that their perspective addresses glaring flaws in the conventional sociological approaches to research (Blumer1969). Ethnomethodologists, however, contradicted that their approach constitutes a lopsided sociology, nothing is sacred, and even the most basic concepts of conventional sociology must be "respecified" (Garfinkel 2002, p.114-20). Those who find ethnomethodology and symbolic interactionism similar often note that although ethnomethodologists and symbolic interactionists use such concepts as "meaning" and "process.", the central argument is that symbolic interactionism and ethnomethodology fundamentally differ on how to interpret the meaningful nature of social interaction. Both perspectives understand the meanings of social actors in their everyday life but using quite different methods (Gallant and Kleinman, 1983).

The next school of thought is phenomenology. As a philosophy of knowledge and qualitative research approach, its major aim is to "reduce" the experience individuals have about a certain phenomenon so that they can finally create the description of the universal essence to grasp the very nature of the thing (VanManen, 1990, p. 177). According to Sokolowski (2000), "human beings indicate the way things are, yet their manner of doing so has often been misrepresented by traditional philosophy, to which phenomenology provides a corrective and restorative way. In the ELT field, e.g. that might include understanding the experience of learners making efforts to create or negotiate meaning in English." Likewise, having a better understanding of such a phenomenon can help teachers become more aware of the students' language learning experiences, or help the administrators make better structured courses. A particularly important point concerning this is that phenomenological research does not apply any empirical justification (Abrams, 2014), but usually involves the method of in-depth interviews to collect data (Creswell, 2007 cited in Slown and Bowe, 2013). In a broader sense, phenomenology and grounded theory are the two most significant research approaches used by novice researchers (Heigham and Croker, 2009). Strong evidences stress that analogies exceed differences between them. Then the following section focuses on the similarities and differences between ethnography and grounded theory.

To begin with, ethnography involves the study of the cultural characteristics of a group in a real world rather than in laboratory settings, and the researchers are interested in behavior, language and the interaction of the members of the 
selected group (Mitchell \& Cody 1993; Leedy \& Omrod, 2005; Creswell, 2007). Watson-Gegeo and Ulichny (1998) identified its defining characters as an approach that emphasizes the importance of context and subjective perceptions of the research enterprise. Long (1990) argued that the main purpose of educational ethnography is to describe classroom practice and be subjected to experimental manipulation. The researcher makes no attempt to isolate or handle the phenomena under investigation, and insights and generalizations come from close contact with data instead of the theory of language teaching and practice (Nunan, 2012). Data is collected from field work: observation and interview (Creswell, 2009). This leaves it to a position that ethnography has been criticized for its failure to achieve reliability and validity. However, in the fields of language learning and teaching, the ethnographic approaches have some special offerings, such as: it is more valuable when little is known about a context or situation (Mackay and Gass, 2005).

However, the practice of deriving theory from data rather than other way round is symptomatic of grounded theory. Long (1986) and Gregg (1989) argued that this 'theory then data' approach is more rational and efficient than 'data then theory'. In this method, the researcher uses the data obtained for developing and finding a theory in the process of his/her studies (Leedy \& Ormrod, 2005). Its particular purpose is to "move beyond description" (Creswell, 2007, p.62), so that the researcher can "generate" and "discover" a theory. Strauss and Corbin (1998) regarded that in grounded theory, data collection; analysis and eventual theory are closely related to each other. In contrast to phenomenology, grounded theory is rarely used by novice researchers because of its complexity (Heigham and Croker, 2009). However, this cannot stop it from being one of the most used methods in qualitative studies (Martin \& Turner, 1986; Ng \& Hase, 2008). Much like other qualitative research methods, the researcher is the main body involved in data collection and analysis. Interviews, observation and other qualitative research techniques are used as well.

\subsection{Strengths and Weakness}

Although both of the quantitative and qualitative researchers believe that they get to know the society through various means, methods to present their thoughts and findings (Becker, 1986), both approaches have their advantages and limitations (Hossain, 2012). According to Thomson (2011), the qualitative method generates new theories and the quantitative method verifies them. Moreover, they are regarded as models to summarize or predominant approaches in social science that differ in their theoretical basis or philosophical assumptions (Hudson and Ozanne, 1988).

A critique of qualitative research has been built up over the years. Bryman (1999)firstly pointed out that qualitative usually begins with open ended questions which researchers criticized as being impressionistic and subjective, relying too much on the researchers' often unsystematic views, close relationships they have with the people studied. Then, the difficulty of replicating a qualitative study is a tendency as well as a problem, its reliance on the researchers' imagination and creativity. Next, generalization is not easy. Williams (2000) has argued that qualitative researchers seem to produce generalizations for the small numbers of individuals in a certain organization or locality, but cannot be seen applicable to a broader setting. Finally, the reports and process of qualitative research are often obscure (Bryman and Burgess, 1994a), and it is not clear how the analysis is conducted, which is called the lack of transparency.

Despite the limitations, there are several assumptions carrying many positive methodological benefits, and three are noted here. First, qualitative research in the interpretivist research paradigm is "a basic set of beliefs that guides action" and can answer questions about how and why something is happening (Guba, 1990. p17). Second, although qualitative methods provide less explanation of variance in statistical terms than quantitative methods, they can yield data from which theories can be processed and develop richer explanations of how and why processes and out-comes occur (Marcus and Robey, 1988). Third, qualitative research is deemed to be more fluid and flexible than quantitative in that it emphasizes original findings and the possibility for changing research plans. It also produces rich data which means data is in great depth. Therefore, the value of qualitative approaches in social, behavioural, organizational, and evaluation research manifested in studies and research methodology texts (Argyris, 1985; Bredo and Feinberg, 1982b; Lincoln and Guba, 1985; Miles and Huberman, 1984; Mintzberg, 1973; Patton, 1978; Van Maanen, 1983c) has been advanced and practiced and is increasingly recognised in organizational research. Richards (2003) argued that it is not just a body of knowledge, but a craft.

Now, the above discussions can be summarized as: quantitative research has a strong reputation, even in the social sciences where early critiques of the lack of empirical data pushed social science researchers to try more hard science methods such as the positivist approach, using more quantitative methods (Austin, 1978). Essentially, qualitative research is used to explore complex human interactions to understand lived experiences. This research specialises in 
sensitive topics or topics based on personal values, such as religion, sexuality, gun control, or the death penalty (Nuttall et al., 2011), whereas quantitative methods can only address such issues by providing limited data (Thomas, unknown). Therefore, qualitative research plays a key role in pushing previous limits of theories regarding quantitative empiricism (Doz, 2011). To show justice, Reichardtt and Cook (1979) insisted that although a binary distinction between them exists, researchers should adhere to the principles of one paradigm while simultaneously assuming methods and values of the other.

\subsection{Link between Interpretivism and Qualitative Research}

From the foregoing, the study has outlined the interpretivism and qualitative research separately. This section will highlight their relationship with each other. The link between them is obvious and there are several reasons for this.

First of all, as has been discussed earlier, the quantitative paradigm is based on positivism (Sale, Lohfeld and Brazil, 2012), aims of which are directed at the law-like proposals. Whereas in contrast, the qualitative paradigm is based on interpretivism (Altheide and Johnson, 1994; Kuzel and Like, 1991; Secker et al., 1995) and constructivism (Guba and Lincoln, 1994a), the purpose of which is understanding the subjective meaning by experience. Max Weber (1864-1920) remarked that there is a key difference between the purpose of understanding the natural and social world. According to Ritchie et al. (2013), "the school of thought that emphasizes the importance of interpretation and observation in understanding the social world is called interpretivism, which is integral to qualitative research." Finally, some researchers have agreed that the interpretivism is the foundation of qualitative research (Mason, 1996, p3). Holloway and Wheeler (2013) held a similar view that the interpretive approach which focuses on social reality and life experience of human beings is the root of qualitative research.

However, some others partially disagree. Qualitative research is often associated with interpretivism, but alternatives do exist (Goldkuhl, 2012).Other paradigms for qualitative methods have been proposed such as positivism (Devers, 1999), post-positivism (Marshall, 1990; Devers, 1999), postmodernism (Creswell, 1998), and critical theory (Creswell, 1998). For example, a legitimate argument would have been for Howe and others who appear to favour this position (e.g. Reichardt and Rallis, 1994) to claim that the paradigmatic debate was oversimplified by a positivism-interpretivism split, and that the qualitative paradigm actually espoused positivism. The philosophical distinctions between them have become so obscure that researchers are impressed that the differences between the two are merely technical (Smith and Heshius, 1986). The next section will elaborate on the contribution of qualitative research to ELT.

\section{Methodology}

In order to examine the contributions of Qualitative Research to ELT, the research articles of three Mainland China based academics published in international journals will be cited. A careful investigation will be conducted to determine whether these three articles use methods that are qualitative in nature or otherwise. This section will also demonstrate how the qualitative method best fits to reveal problems associated with ELT.

Article one: "Chen, Q., Kettle, M., Klenowski, V., \& May, L. (2013). Interpretations of formative assessment in the teaching of English at two Chinese universities: a sociocultural perspective. Assessment \& Evaluation in Higher Education, 38(7), 831-846."

Article two: "Yan, J. X., \& Horwitz, E. K. (2008). 'Learners' perceptions of how anxiety interacts with personal and instructional factors to influence their achievement in English: A qualitative analysis of EFL learners in China'. Language Learning, 58(1), 151-183."

Article three: "Fang, X., \& Garland, P. (2014). 'Teacher Orientations to ELT Curriculum Reform: An Ethnographic Study in a Chinese Secondary School'. The Asia-Pacific Education Researcher, 23(2), 311-319. “

The following paragraphs form reasons for the selection and then a critique of the articles.

Firstly, qualitative research interprets social actors' experiences, perceptions, feelings, and facts (Maykut and Morehouse, 1994). Similarly, all three articles contemplated those factors that can help or impede English teaching and learning: article one attempted to explore the phenomena how two Chinese universities implement formative assessment with many key principles derived from western contexts to suit College English teaching, and the article adopts a sociocultural perspective to compare and analyze. Article two aimed to explore the influence of anxiety upon EFL learners' achievements. It also specified the ways in which anxiety and other variables interact with language learning from a learner's perspective. Article three examined the teachers' orientations towards NEC (New English Curriculum) and the forces that influence their orientations and practices, whist proposing a number of issues 
facilitating the need for new curriculum implementation.

Secondly, with regard to positive research approaches used which are all qualitative in nature, article one adopted a qualitative case study which enabled in-depth exploration (Yin 2003) to address two research questions:(1) How is formative assessment interpreted in the College English policies of both Chinese universities? (2) How do teachers understand and take up formative assessment in practice? Two major data-sets were generated to address the questions and they have looked at localized responses of the two universities to government policy. In article two, grounded theory was used to achieve a generation of the model based on the participants' perception of the anxiety level in a specific learning context. The researcher designed the three-stage grounded theory analysis (GTA) of interviews which are semi-structured and audio recorded to address the research questions. Consistent with the (GTA) procedures, the data collected was analyzed by three steps, each of which are important components (Miles, 1997; Northcutt, 1999; Northcutt et al., 1998): thematic analysis, generation of variables and interrelationship diagraph analysis. Article three employed teachers' accounts and participant-observer field notes within a 15-month ethnographic study. They all use the common qualitative data collection tool, namely, interviews. It is evident that the authors of all three articles have maintained a good rapport with and ensured direct interaction with the participants. All the three interpreted and analyzed the data in words not numbers. Similarly, the qualitative data was not quite as large as the quantitative data. Article one involves interviewing nine teaching staff; article two engages twenty one undergraduates and article three seven teachers.

Thirdly, all the three articles can also be considered as phenomenological research as the key focus is interpreting human experiences. This section draws attention to the data analysis part of every article. The authors in article one presented their findings through the observation of assessment practices in classrooms of two Chinese universities. Article two, observed twenty-one participants of high, moderate and low anxiety level experiences of learning in a Non-Western (EFL) context. Article three, however, was based on perspectives gained from 15 months' ethnographical study and it shed light on some commonly discussed issues locally and personally experienced by teachers. Hence, the articles ae regarded as phenomenological studies as well.

Additionally, as far as arguments are concerned, the researchers in all three articles unearthed the fact that the ongoing historical and cultural influences are calling for a reform of English Education traditions in China. For example, article one identified some consistency in localized interpretations of formative assessment focusing on process and student participation. The purpose was to discover how sociocultural conditions of the Chinese context mediate and adapt to Western principles. Article two confirmed the findings of quantitative research on the negative influences of anxiety on language achievement with those of the qualitative investigation. It has broadened our perspective of the interrelationship between anxiety and personal and sociocultural factors in different contexts to direct further study. Article three examined the teachers' orientations as well as local and personal experiences. It looked into how they affected the new curriculum implementation to promote the students' all-round ability to use English within the scope of the NEC policy.

There are many merits of the three articles to discuss the issues concerning contribution of qualitative to ELT. However, shortcomings do exist .For example; there is little or no information about the consent form, ethical considerations, use of qualitative data analysis software and constructive suggestions.

\section{Summary of Findings}

As far as the above arguments are concerned, all of the findings of the journal articles prove that qualitative research is a more contributive research paradigm than any others in the ELT field. We have chosen to focus on qualitative methods because there are several reasons for rejecting to simply refining and using quantitative procedures. The first reason is that some commentators like Crombie with Davies (1996) have characterized qualitative research as being 'descriptive', using this to distinguish it from quantitative research. The intention of qualitative research is seen as understanding meanings and providing explanations, rather than generate representative data. The second one is that, in ELT the recent qualitative research that has emerged and the theory generation or the issues in the language learning field that is more insightful than quantitative (Cummins, 1994). It is because that "quantitative research looks for the answer to the questions with how much, how many, how often, to what extent .Rather, qualitative always investigate the answers to the question with why." (Hancock, 1998 and Rasinger, 2013). Thirdly, much of the experimental research in ELT has been criticized as being limited to answering questions about program effectiveness (Cummins, 2000). Even large scale quantitative data that is well designed, can only provide a starting point of inquiry of a program. Duff (2007) pointed out that the qualitative researches conducted in classrooms are typically focused on instructional behaviors, interactions and teaching outcomes related to classroom activities. 


\section{Conclusion}

The main purpose of this study is to verify the benefits of qualitative research in ELT. So we can safely come to the conclusion that qualitative research can contribute to ELT in many ways. First, qualitative research is employed to provide rich, in-depth descriptions of phenomena bringing about deeper thoughts (Weick, 2007). Qualitative research also safeguards researchers against the accepted norms by asking more probing questions (Doz, 2011). Qualitative methods can also be able to test theory using theoretical methods to investigate phenomenon and provide additional insight into the theory (Bluhm et al., 2011; Lee, Mitchelle, \& Sablynski, 1999). According to Eisenhardt (1989), case study methods involving qualitative research have a high likelihood of generating novel theory. All in all, quantitative research does not benefit the field of ELT as efficiently and extensively as qualitative research does. The combination of multiple methods, empirical materials, conceptions and observers in a single qualitative study is a strategy bringing challenges to any investigation (Flick, 1992, p.194).

To this end, the studies selected reveal that China has already risen to become one of the major consumers and producers of language learning and teaching research (Yg, Lichun \& Jun 2001). According to statistics from domestic papers published in four core language journals from 1988 to 1997, only 2\% applied qualitative methods (Gao et al., 1999). However, Lichun \& Jun (2001) compared trends in research methods in applied linguistics and TESOL between China and the West, from the year 1978 to1997, and noted "a shift toward the qualitative direction" and claimed that "from the mid-1990s, the percentage of qualitative studies has been approaching that of quantitative studies"

Also in China, the discrepancies between intended policy outcomes and the actual practice are reported. We therefore have concluded this paper by offering some suggestions to ELT in China. Curriculum reform like compulsory subject in primary schools, communicative language teaching and task-based instruction call for Chinese researchers and education workers to effectively explore how learners acquire English language skills and how English language teachers pursue the desired objectives. Meanwhile, the study has indicated some important limitations. In particular: with regard to ELT practice, there are many factors like the teachers' lack of confidence, the difficulties in classroom management that constrain them from CLT methods in Confucian heritage cultural contexts. Therefore, this essay has presented these issues requiring further investigation.

\section{Acknowledgements}

I would like to thank Dr Caroline Linse (Senior Lecturer, School of Education, Queen's University Belfast, UK) for her expert advice and comments on this paper.

\section{References}

Abrams, T. (2014) Flawed by Dasein? Phenomenology, Ethnomethodology, and the Personal Experience of Physiotherapy. Human Studies, pp. 1-16. http://dx.doi.org/10.1007\%2Fs10746-014-9316-2

Adamson, B. (2004). China's English: A history of English in Chinese education (Vol. 1). Hong Kong University Press. http://dx.doi.org/ 10.1353/cri.2008.0014

Allwright, D. (2014). Observation in the language classroom. Routledge. http://dx.doi.org/10.1111/j.1944-9720.1977.tb03041.x

Altheide, D. L., \& Johnson, J. M. (1994). Criteria for assessing interpretive validity in qualitative Research. In: N. K. Denzin, \& Y. S. Lincoln (eds.), Handbook of Qualitative Research. Thousand Oaks, CA: Sage Publications, pp. 485-499. http://dx.doi.org/10.4135/9781848607927

Ann Chih Lin. (1998). Bridging Positivist and Interpretivist Approaches to Qualitative Methods Policy Studies Journal, 26(I), (162-180). http://dx.doi.org/10.1111/j.1541-0072.1998.tb01931.x

Austin, D. (1978). Educational paradoxes and possibilities. http://dx.doi.org/10.1300/J079v02n02_02

Barbour, R. (2013). Introducing qualitative research: A student's guide. Sage. http://dx.doi.org/10.3316/QRJ0802145

Bateson, G. (1972). Steps to an ecology of mind: Collected essays in anthropology, psychiatry, evolution, and epistemology. University of Chicago Press. http://dx.doi.org/+DOI:10.1007/s11186-014-9222-7 $\cdot 1.06$

Becker, H. S. (1986). Doing things together: Selected papers. Northwestern Univ Pr. http://dx.doi.org/10.1017/S0021875800022271 
Berg, B. L., Lune, H., \& Lune, H. (2004). Qualitative research methods for the social sciences (Vol. 5). Boston, MA: Pearson.

Bernstein, R. J. (1976). The restructuring of social and political thought. http://dx.doi.org/10.1177/0191453704045761

Blumer, H. (1969). The methodological position of symbolic interactionism. Symbolic interactionism: Perspective and method (pp. 1-60). http://dx.doi.org/10.1525/si.2001.24.2.237

Bogdan, Robert. (1972). Participant Observation in Organizational Settings. Syracuse: Syracuse University.

Bryman, A. (1984). The debate about quantitative and qualitative research: a question of method or epistemology? British Journal of Sociology, 75-92.

Bryman, A., \& Burgess, R. (1999). 'Introduction: Qualitative research methodology-A review'. Qualitative research, 1.

Bryman, A., \& Burgess, B. (Eds.). (2002). Analyzing qualitative data. Routledge.

Brooke, M. (2013). 'Which research paradigm for TESOL?' Theory and Practice in Language Studies, 3(3), 430-436. http://dx.doi.org/:10.1080/09650792.2011.569160

Cryer, P. (2006). The research student's guide to success. McGraw-Hill.

Cummins, J., \& Davidson, C. (2007). Research and Teacher Education in ELT: Meeting New Challenges. http://dx.doi.org/:10.1007/978-0-387-46301-8

Cummins, J., \& Davison, C. (2007). International handbook of English language teaching (Vol. 15). Springer Science $\&$ Business Media.

Creswell, J. W. (2013). Research design: Qualitative, quantitative, and mixed methods approaches. Sage publications.

Cumming, A. (1994). Alternatives in TESOL research: Descriptive, interpretive, and ideological orientations. Tesol Quarterly, 28(4), 673-703. http://dx.doi.org/: 10.2307/3587555

Denzin, \& Lincoln (1994). Handbook of Qualitative Research. Beverly Hills, CA: Sage. p. 536.

Dennis, A. (2011). Symbolic interactionism and ethnomethodology. Symbolic Interaction, 34(3), 349-356. http://dx.doi.org/10.1525/si.2011.34.3.349

Devers, K. J. (1999). How will we know 'good' qualitative research when we see it? Beginning the dialogue in health services research. Health Serv. Res. 45 (5 Part II), 1153-1188.

Ding fang, S., \& Weifen. H. (2009). Sixty Years of Chinese Language Teaching Theory and Research: Retrospect and Prospect. Foreign Language Teaching. 30(6), 37-44.

Doz, Y. (2011). Qualitative research for international business. Journal of International Business Studies, 42(5), 582-590. http://dx.doi.org/10.1057/jibs2011.18

Duff, P. A. (2007). Qualitative approaches to classroom research with English language learners. In International handbook of English language teaching (pp. 973-986). Springer US.

Flick, U. (1992). 'Triangulation revisited: Strategy of validation or alternative?' Journal for the theory of social behavior, 22(2), 175-197.

Gallant, M. J., \& Kleinman, S. (1983). Symbolic interactionism vs. Ethnomethodology*. Symbolic Interaction, 6(1), $1-18$.

GAO, X., Liao, Y., \& Li, Y. (2014). Empirical studies on foreign language learning and teaching in China (2008 2011): A review of selected research. Language teaching: The international abstracting journal for language teachers and applied linguistics, 47(1), 56-79.

Gao, Li, Lv. (1999). Trend of research methods in Chinese and Western AppliedLinguistics .Foreign language teaching and research, 2, 8-16.

Gerring, J., \& Thomas, C. W. (2011). Quantitative and qualitative: A Question of comparability. International Encyclopedia of political science: Sage, 7, 2189-2196.

Guba, E. G., \& Lincoln, Y. S. (1994a). Competing paradigms in qualitative research. In N. Ryan, G. W., Bernard, H. R., Denzin, N., \& Lincoln, Y. (2000), Handbook of qualitative research.

Flick, U. (1992). Triangulation Revisited: Strategy of Validation or Alternative? Journal forthe Theory of Social Behaviour, 22, 169-197. 
Goldkuhl, G. (2012). Pragmatism vs interpretivism in qualitative information systems research. European Journal of Information Systems, 21(2), 135-146.

Hancock, B., Ockleford, E., \& Windridge, K. (1998). An introduction to qualitative research. Nottingham: Trent focus group.

Heidegger, M. (2004) Being and Time. Oxford: Blackwell.

Heigham, J., \& Croker, R. A. (Eds.). (2009). Qualitative research in applied linguistics: A practical introduction. Palgrave Macmillan.

Holloway, I., \& Wheeler, S. (2013). Qualitative research in nursing and healthcare. John Wiley \& Sons.

Hossain, D. M. (2012). 'Mixed Method Research: An Overview'. Postmodern Openings, (12), 137-151.

Howe, K. R. (1992). Getting over the quantitative-qualitative debate. American Journal of Education, 100, $236-257$.

Jennifer Mason. (1996). Qualitative researching. London. Sage.

Lazaraton, A. (2000). Current trends in research methodology and statistics in applied linguistics. TESOL Quarterly, 34(1), 175-181.

Lin, Ann Chih. Bridging Positivist and Interpretivist Approaches to Qualitative Methods. Policy Studies Journal, 26(I), Vol.1998 (162-180).

Maykut, P., \& Morehouse, P. (1994). Beginning Qualitative Research: A P philosophic and Practical Guide. London and New York: RoutledgeFalmer.

Markus, M. L., \& Robey, D. (1988). Information technology and organizational change: causal structure in theory and research. Management science, 34(5), 583-598.

Mangubhai, F., P. Marland, A. Dashwood, \& J-B. Son (2004). Teaching a foreign language: One teacher's practical theory. Teaching and Teacher Education, 20(3), 291-311.

Miller, L., \& D. Aldred. (2000). Student teachers' perceptions about communicative language teaching methods. RELC Journal, 31(1), 1-22.

Miles, C. L. (1997). Community college faculty pay for performance: A case study (Doctoral dissertation, University of Texas at Austin.

Merriam, S. B. (2014). Qualitative research: A guide to design and implementation. John Wiley \& Sons.

McPherron, P. R. (2008). Internationalizing teaching, localizing English: Language teaching reforms through a south Chinese university.

Norman K. Denzin. (2001). Interpretive interactionism (Vol. 16). Sage.

Nuttall, P., Shankar, A., \& Beverland, M. B. (2011). 'Mapping the unarticulated potential of qualitative research'. Journal of Advertising Research, 51, 153-163. http://dx.doi.org/10.2501/ jar-51-1-153-166

Northcutt, N., Miles, C., Robins, L., \& Ellis, L. (1998). Using qualitative research tools for research and planning. Working paper, University of Texas at Austin.

Northcutt, N. (1999). Qualitative analysis. Unpublished course supplement materials, University of Texas, Austin.

Nunan, D. (1992). Research Methods in Language Learning.Cambridge: CUP. 53-73. Nazari, A. (2007). EFL teachers' perception of the concept of communicative competence. ELT Journal.

Ponterotto, J. G. (2006). Brief Note on the Origins, Evolution, and Meaning of the Qualitative Research Concept Thick Description. The Qualitative Report, 11(3), 538-549. Retrieved from http://nsuworks.nova.edu/tqr/vol11/iss3/6

Qin, J. (1999). The status quo of FLT at tertiary level. Foreign Language Teaching and Research, 117, 3-6.

Rasinger, S. M. (2013). Quantitative research in linguistics: An introduction. A\&C Black.

Rahman, M. S. (2015). The contribution made by qualitative research to TESOL. International Journal of English Language Teaching, 3(2), pp. 1-14, April Pang, J,

Reeves, T. C. (2011). Can educational research be both rigorous and relevant. Educational Designer, 1(4), 1-24.

Richards, K. (2009). Trends in qualitative research in language teaching since 2000. Language Teaching, 42(02), 147-180.

Ritchie, J., Lewis, J., Nicholls, C. M., \& Ormston, R. (Eds.). (2013). Qualitative research practice: A guide for social 
science students and researchers. Sage.

Rossman, G. B., \& Rallis, S. F. (2003). Learning in the Field: An Introduction to Qualitative Research. (2nd ed.) Thousand Oaks, CA: Sage. pp. 31-60.

Sloan, A., \& Bowe, B. (2013). Phenomenology and hermeneutic phenomenology: the philosophy, the methodologies, and using hermeneutic phenomenology to investigate lecturers' experiences of curriculum design. Quality and Quantity, 48(3), 1291-1303.

Sokolowski, R. (2000). Introduction to phenomenology. Cambridge University Press.

Sale, J. E., Lohfeld, L. H., \& Brazil, K. (2002). Revisiting the quantitative-qualitative debate: Implications for mixed-methods research. Quality and quantity, 36(1), 43-53.

Seymour, F. W., \& Davies, E. (2002). Using action research to facilitate change in child protection services. Journal of community psychology, 30(5), 585-590.

Tavallaei, M., \& Talib, M. A. (2010). A General Perspective on Role of Theory in Qualitative Research. Journal of International Social Research, 3(11).

Thomas, J. E. Scholarly Views on the Nature of Theory.

Van manen, M. (1990). Researching lived experience: Human science for an action centred pedagogy. Ontario: The Althouse Press.

Van Lier, L. (1988). The classroom and the language learner: Ethnography and second language classroom research. London: Longman.

Wang. M (2001) Qualitative Research Method in Second Language Acquisition Studies: a Critical Review. Language Teaching, 56-79.

Watson-Gegeo, K. A., \& Ulichny, P. (1988). Ethnographic Inquiry into Second Language Acquisition and Instruction.

Wei, Y. (2013). A Study on the Functions of Western Cultural Non-Verbal Behavior in English Classroom in China. English Language Teaching, 6(12), 189.

Williams, M. (2000). Interpretivism and generalisation. Sociology, 34(2), 209-224.

Wright, G. H. (2004). Explanation and understanding. Cornell University Press.

Yihong, L. Lichun, \& L. Jun (2001). Trends in qualitative research in language teaching since 2000. English for Specific Purposes, 20, 1-14. 